\title{
Hematopoietic stem cell mobilization with the reversible CXCR4 receptor inhibitor plerixafor (AMD3100)_-Polish compassionate use experience
}

\author{
Grzegorz Wladyslaw Basak • Wanda Knopinska-Posluszny • Magdalena Matuszak • \\ Elzbieta Kisiel • Dorota Hawrylecka • Anna Szmigielska-Kaplon • \\ Donata Urbaniak-Kujda • Jaroslaw Dybko • Patrycja Zielinska • \\ Anna Dabrowska-Iwanicka • Joanna Werkun • Piotr Rzepecki • \\ Wiktoria Wroblewska • Wieslaw Wiktor-Jedrzejczak
}

Received: 18 June 2010 / Accepted: 30 September 2010 /Published online: 12 October 2010

(C) The Author(s) 2010. This article is published with open access at Springerlink.com

\begin{abstract}
Recent developments in the field of targeted therapy have led to the discovery of a new drug, plerixafor, that is a specific inhibitor of the CXCR4 receptor. Plerixafor acts in concert with granulocyte colonystimulating factor (G-CSF) to increase the number of stem cells circulating in the peripheral blood (PB). Therefore, it has been applied in the field of hematopoietic stem cell mobilization. We analyzed retrospectively data regarding stem cell mobilization with plerixafor in a cohort of 61 patients suffering from multiple myeloma $(N=23)$, non-
\end{abstract}

G. W. Basak $(\square) \cdot$ W. Wiktor-Jedrzejczak

Department of Hematology, Oncology and Internal Diseases,

The Medical University of Warsaw,

1 A Banacha Str.,

02-097 Warsaw, Poland

e-mail: gbasak@ib.amwaw.edu.pl

W. Knopinska-Posluszny

Medical University of Gdansk,

Gdansk, Poland

M. Matuszak

Karol Marcinkowski University of Medical Sciences,

Poznan, Poland

E. Kisiel

Institute of Hematology and Transfusion Medicine,

Warsaw, Poland

D. Hawrylecka

Jagiellonian University School of Medicine,

Krakow, Poland

A. Szmigielska-Kaplon

Medical University of Lodz,

Lodz, Poland
Hodgkin's lymphoma $(N=20)$, or Hodgkin's lymphoma $(N=18)$. At least one previous mobilization attempt had failed in $83.6 \%$ of these patients, whereas $16.4 \%$ were predicted to be poor mobilizers. The median number of CD34+ cells in the PB after the first administration of plerixafor was $22 / \mu \mathrm{L}$ (range of $0-121$ ). In total, $85.2 \%$ of the patients proceeded to cell collection, and a median of two (range of 0-4) aphereses were performed. A minimum of $2.0 \times 10^{6} \mathrm{CD} 34+$ cells per kilogram of the patient's body weight (cells $/ \mathrm{kg}$ b.w.) was collected from $65.6 \%$ of patients,

\section{Urbaniak-Kujda $\cdot$ J. Dybko \\ Wroclaw Medical University, \\ Wroclaw, Poland \\ P. Zielinska \\ Medical University of Silesia, \\ Katowice, Poland}

A. Dabrowska-Iwanicka

Maria Sklodowska-Curie Memorial Cancer Center

and Institute of Oncology,

Warsaw, Poland

\section{J. Werkun}

Lower Silesian Centre for Cellular Transplantation,

Wroclaw, Poland

P. Rzepecki

Military Institute of Health Services,

Warsaw, Poland

W. Wroblewska

Warsaw School of Economics,

Warsaw, Poland 
and the median number of cells collected was $2.67 \times 10^{6}$ CD34+ cells $/ \mathrm{kg}$ b.w. (0-8.0). Of the patients, $55.7 \%$ had already undergone autologous stem cell transplantation, and the median time to neutrophil and platelet reconstitution was 12 and 14 days, respectively. Cases of late graft failure were not observed. We identified the diagnosis of nonHodgkin's lymphoma and previous radiotherapy as independent factors that contributed to failure of mobilization. The current report demonstrates the satisfactory efficacy of plerixafor plus G-CSF for stem cell mobilization in heavily pre-treated poor or predicted poor mobilizers.

Keywords Plerixafor -AMD3100 - Mobilization .

Stem cells $\cdot$ Transplantation

\section{Introduction}

Autologous stem cell transplantation (autoSCT) is a widely established treatment option in patients suffering from multiple myeloma (MM) or lymphomas $[1,2]$. In $M M$, despite the development of new drug therapies, autoSCT still remains the gold standard treatment in those patients who qualify on the basis of their age and general condition. In MM, autoSCT is aimed at achieving remission or extending the remission period. In non-Hodgkin's lymphoma (NHL) and Hodgkin's lymphoma (HL), autoSCT is reserved especially for patients with aggressive disease with a poor prognosis, or those who have relapsed after remission had been achieved previously. In contrast to MM, cure of the disease is the main aim of autoSCT in lymphoma.

AutoSCT involves high-dose myeloablative chemotherapy, which is supposed to eradicate the tumor, followed by an infusion of autologous hematopoietic stem cells (HSCs) to rescue hematopoiesis in the patient. Nowadays, autologous HSCs are usually isolated from the peripheral blood (PB) of patients, instead of being aspirated from the bone marrow (BM) [3]. However, although HSCs circulate in the PB under physiological conditions, in order to collect a dose of cells that is sufficient for the renewal of hematopoiesis, they need to be mobilized from the BM. According to the literature and common practice, a minimum dose of $\geq 2.0 \times 10^{6} \mathrm{CD} 34+$ cells per kilogram of the patient's body weight (cells/kg b.w.) is required for transplantation [4, 5]. The approaches that are used commonly to mobilize stem cells include the application of granulocyte colony-stimulating factor (G-CSF) either alone or in combination with chemotherapy. The G-CSF is thought to stimulate the production of BM neutrophils, which secrete proteolytic enzymes that cleave the adhesion molecules that attach HSCs to the stroma of the BM [6]. In this way, HSCs are released into the circulation. Stromaderived factor-1 (SDF-1) is probably the key molecule that is cleaved. SDF-1 is produced by BM stromal cells and is found within the BM as both a protein attached to the cell membrane and a soluble factor [7]. The SDF-1 receptor, CXCR4, is expressed differentially at the surface of multiple types of blood cells, which include neutrophils and stem cells/progenitors. SDF-1 acts chemotactically on these cells to attract them to the BM and to prevent them leaving the $\mathrm{BM}$ niche. Unfortunately, a proportion of patients fail to release sufficient CD34+ cells after the mobilization procedure, which results in a lack of material for autoSCT. The failure rate of primary mobilization was reported to be as high as $5 \%$ in $\mathrm{MM}$ and up to $35 \%$ in lymphomas $[6,8]$. The failure rate of re-mobilization seems to be even higher [9].

On the basis of recent reports, it seems that inhibition of the CXCR4 receptor might provide an important adjunct to the multispectral action of G-CSF. A specific inhibitor of CXCR4, plerixafor (AMD3100, Mozobil), has been shown to act in synergy with G-CSF to improve its mobilizing capacity significantly $[10,11]$. Moreover, it has been shown to have a good safety profile, with side effects that are limited in general to a low degree of nausea, diarrhea, or skin reactions at the injection site, if any. Before the drug was made available commercially, it was provided to American and European transplant centers free of charge, within the Compassionate Use Program (CUP). The current report summarizes the outcome of HSC mobilizations based on the use of plerixafor that were carried out within the CUP in 61 patients in Poland.

\section{Patients and methods}

\section{Study design}

The study has been performed in accordance with the ethical standards laid down in the 1964 Declaration of Helsinki. The approval by the ethics committee was not required, as plerixafor was used according to registration guidelines. All patients gave their informed consent prior to their inclusion in the study. The recommended protocol for mobilization included a daily injection of G-CSF $(10 \mu \mathrm{g} / \mathrm{kg})$ administered subcutaneously (s.c.) each morning for four consecutive days before the administration of plerixafor; however, clinicians were permitted to administer G-CSF according to the local practice guidelines. On the evening of the fourth day, at approximately 10 p.m., patients received an injection of plerixafor $(240 \mu \mathrm{g} / \mathrm{kg}$ s.c.). The following morning, it was recommended that the patients received their dose of G-CSF at least $1 \mathrm{~h}$ before apheresis, after which HSCs were isolated. This procedure was then repeated, for up to 3 days of administration of plerixafor in total, to give a maximum of seven injections of G-CSF and three aphereses. 
The investigators could decide to discontinue the mobilization procedure if the patient failed to release a satisfactory number of CD34+ cells into the $\mathrm{PB}$ or they failed to collect enough cells to warrant continuation. Alternatively, the mobilization procedure could be stopped earlier if the required number of $\mathrm{CD} 34+$ cells has been collected. Counts of nucleated cells (NCs) and CD34+ cells in $\mathrm{PB}$ and in apheresis products were evaluated at local laboratories. The aphereses and cell processing followed local standard operating procedures that had been elaborated in each center. The timing and protocol of autoSCT were also based on individual clinical decisions. If insufficient cells were collected following mobilization with plerixafor and G-CSF, cells could be pooled for transplantation with those collected at other times. The recovery of neutrophils and platelets was measured in accordance with site practices, and patients were monitored for graft durability and disease status in a routine fashion. The criteria used to evaluate efficacy were the PB CD34+ cell count, apheresis yield, engraftment of neutrophils and platelets, and graft durability.

\section{Inclusion and exclusion criteria}

Physicians were requested to complete regulatory documents, which included informed consent forms, and to agree to follow the protocol provided by the manufacturer of plerixafor. Patients had to meet the following criteria to receive plerixafor: (1) aged 18 to 78 years with a diagnosis of HL, NHL, or MM; (2) eligible to undergo autoSCT transplantation; (3) previous conventional therapies for HSC collection had failed, or on the basis of a low PB CD34+ cell count following conventional mobilization therapy, the physician did not think there was a reasonable chance of collecting enough cells; (4) adequate cardiac, renal, and pulmonary function sufficient to undergo apheresis and transplantation, i.e., eligible by institutional standards for autoSCT; (5) WHO performance status of 0 or 1 ; (6) white blood cell (WBC) count $>2.5 \mathrm{G} / \mathrm{L}$ and absolute neutrophil count $>1.5 \mathrm{G} / \mathrm{L}$; (7) platelet (Plt) count $>85 \mathrm{G} / \mathrm{L}$; serum creatinine $\leq 1.5 \mathrm{mg} / \mathrm{dL}$; (8) serum aspartate aminotransferase/serum glutamic oxaloacetic transaminase, serum alanine aminotransferase (ALT)/serum glutamic pyruvic transaminase, and total bilirubin below the two-fold upper limit of normal; (9) no active infection with hepatitis B or C; (10) signed informed consent; and (11) agreed to use an approved form of contraception, when needed.

The exclusion criteria were (1) a diagnosis of any acute or chronic leukemia (including plasma cell leukemia) or myelodysplastic syndrome (for patients with MM, a PB smear was evaluated within $24 \mathrm{~h}$ before the first dose of plerixafor; patients who showed the presence of plasma cells or blasts that indicated plasma cell leukemia should have been excluded from receiving plerixafor; (2) a comorbid condition that, in the view of the treating physician, rendered the patient at high risk from treatment complications; (3) vasculitis or autoimmune disease; (4) brain metastases, carcinomatous meningitis, or any other malignancy, unless the patient had been free of disease for at least 5 years following therapy with curative intent; (5) clinically significant heart disease, e.g., as indicated by results of an electrocardiography or other study (exercise study, scan) that were suggestive of previously undiagnosed cardiac ischemia, or a history of clinically significant rhythm disturbance (arrhythmia) or other conduction abnormality in the last year; (6) acute infection and/or fever (body temperature $\left.>38^{\circ} \mathrm{C}\right)$; (7) hypercalcemia $(>1 \mathrm{mg} / \mathrm{dL}$ above the upper limit of normal); (8) pregnancy or breastfeeding among women; (9) lack of willingness among patients (male and female) with child-bearing potential to implement adequate birth control; (10) known HIV infection; (11) obesity exceeding $175 \%$ of ideal body weight; and (12) receipt of experimental treatment during mobilization.

\section{Definitions}

A chemotherapy regimen was defined as one or more courses of chemotherapy of a certain type, including conditioning regimens and chemotherapy used for previous and current stem cell mobilization. The number of chemotherapy courses was recorded accordingly. The status of kidney, heart, or liver insufficiency was based on individual assessment by the investigators. Proven poor mobilizers were defined as patients in whom at least one previous mobilization attempt had failed. Predicted poor mobilizers were defined as patients who did not release a satisfactory minimum number of $\mathrm{CD} 34+$ cells into the $\mathrm{PB}$ during the current mobilization or from whom too few CD34+ cells were collected during the initial apheresis to warrant successful continuation. The disease status at the time of mobilization was described as complete remission (CR), partial remission (PR), stable disease (StD), or progressive disease (PD) and was defined according to commonly accepted criteria [12, 13]. The satisfactory number of PB CD34+ cells to allow stem cell collection was defined as $20 \mathrm{CD} 34+$ cells $/ \mu \mathrm{L}$. Successful mobilization was defined as the collection of a total of $\geq 2.0 \times 10^{6} \mathrm{CD} 34+$ cells $/ \mathrm{kg}$ b.w. The day of neutrophil recovery was defined as the first of 2 days with a neutrophil count $\geq 0.5 \mathrm{G} / \mathrm{L}$. The day of platelet recovery was defined as the first of 2 days with a Plt count $\geq 20 \mathrm{G} / \mathrm{L}$, in the absence of transfusion.

\section{Data audit}

All Polish transplant centers were invited to participate in the retrospective study. A letter of invitation was sent on 
January 15, 2010 asking whether the center had ever used plerixafor under the CUP to mobilize stem cells in patients. They were requested to report the total number of patients who had undergone the mobilization procedure, regardless of whether or not they participated in the study and regardless of the success or failure of the outcome. A response was obtained from all the centers, and all of them agreed to submit data regarding all the patients who had undergone the mobilization procedure with plerixafor, without exception. They then received detailed questionnaires and submitted data before February 15, 2010. The follow-up questionnaire was sent on April 1, 2010 and received back before April 30, 2010.

Statistical methods

Categorical data were summarized as the numbers and percentage of patients who fell into each category. The differences between categorical variables were calculated with the $\chi^{2}$ test. Non-categorical data were reported as the median and range as well as the mean and standard deviation (SD). The differences between means were calculated with a one-way ANOVA. The multivariate analysis was performed by logistic regression. All the calculations were carried out using the statistical software SPSS (version 17.0, SPSS Inc. Chicago, IL, USA).

\section{Results}

Patient demographics and characteristics

At the time of the data audit, 61 patients from 11 Polish hematology centers were enrolled in the CUP, and this report comprises the outcomes of all of these patients. One center contributed 17 patients, one 10 patients, one 6 patients, two centers 5 patients each, three centers 4 patients each, and three enrolled 2 patients each. The characteristics of the patients are shown in Table 1 . The majority of the patients were male $(55.7 \%)$, and the median age was 51 years, ranging from 19 to 71 years. The median body weight was $77 \mathrm{~kg}$, but it ranged between 49 and $114 \mathrm{~kg}$. Twenty-three patients $(37.7 \%)$ suffered from MM, 18 (29.5\%) from HL, and 20 (32.8\%) from NHL. Among the last group, eight had a diagnosis of diffuse large B-cell lymphoma, four mantle-cell lymphoma, three marginal

Table 1 Characteristics of patients

\begin{tabular}{|c|c|c|c|c|}
\hline Variable & $\begin{array}{l}\text { All } \\
N=61\end{array}$ & $\begin{array}{l}\mathrm{MM} \\
N=23(37.7 \%)\end{array}$ & $\begin{array}{l}\text { NHL } \\
N=20(32.8 \%)\end{array}$ & $\begin{array}{l}\mathrm{HL} \\
N=18(29.5 \%)\end{array}$ \\
\hline \multicolumn{5}{|l|}{ Gender } \\
\hline Female $(\%)$ & 44.3 & 56.5 & 35.0 & 38.9 \\
\hline Male (\%) & 55.7 & 43.5 & 65.0 & 61.1 \\
\hline Age (years) (median, range) & $51(19-71)$ & $60(48-71)$ & $51(21-64)$ & $26.5(19-57)$ \\
\hline Body weight $(\mathrm{kg}) ; N$ & 55 & 22 & 18 & 18 \\
\hline Median (range) & $77(49-114)$ & $74.5(53-113)$ & $78.5(60-107)$ & $75.5(49-114)$ \\
\hline Radiotherapy (\%) & 24.6 & 26.1 & 25.0 & 22.2 \\
\hline Previous autoSCT (\%) & 18.0 & 34.8 & 5.0 & 11.1 \\
\hline No. of previous chemotherapy courses (median, range) & $12(4-37)$ & $11(4-37)$ & $12(5-17)$ & $12(6-18)$ \\
\hline No. of previous chemotherapy regimens (median, range) & $3(2-7)$ & $3(2-7)$ & $3(2-6)$ & $3(2-5)$ \\
\hline No. of previous mobilization attempts (median, range) & $1(0-4)$ & $1(0-2)$ & $1(0-3)$ & $1(0-4)$ \\
\hline \multicolumn{5}{|l|}{ Disease status } \\
\hline CR $(\%)$ & 37.7 & 17.4 & 45.0 & 55.6 \\
\hline PR $(\%)$ & 47.5 & 73.9 & 35.0 & 27.8 \\
\hline $\mathrm{SD}(\%)$ & 9.8 & 0 & 15.0 & 16.7 \\
\hline PD (\%) & 4.9 & 8.7 & 5.0 & 0 \\
\hline \multicolumn{5}{|l|}{ BM infiltration } \\
\hline $0 \% ; N(\%)$ & $34(68.0)$ & $6(30.0)$ & $13(86.7)$ & $15(100.0)$ \\
\hline$<20 \% ; N(\%)$ & $11(22.0)$ & $10(50.0)$ & $1(6.7)$ & 0 \\
\hline $20-49 \% ; N(\%)$ & $4(8.0)$ & $3(15.0)$ & $1(6.7)$ & 0 \\
\hline $50-89 \% ; N(\%)$ & $1(2.0)$ & $1(5)$ & 0 & 0 \\
\hline $90-100 \% ; N(\%)$ & 0 & 0 & 0 & 0 \\
\hline
\end{tabular}


zone lymphoma, one follicular lymphoma, one malignant lymphocytic lymphoma, one anaplastic lymphoma, one small lymphocytic lymphoma, and one Waldenström's macroglobulinemia. All the patients had been treated previously for their primary disease. Fifteen $(24.6 \%)$ of the patients had been treated with radiotherapy, and 11 $(18 \%)$ had undergone autoSCT previously. Among the latter group, a single patient underwent double autoSCT. All the patients received chemotherapy before the attempt at mobilization. They were treated with a median of 12 chemotherapy courses, ranging between four and 37, which corresponded to a median of three (two to seven) chemotherapy regimens. Fifty-one patients $(83.6 \%)$ had undergone at least one previous failed attempt at stem cell mobilization, whereas 10 patients $(16.4 \%)$ were predicted to be poor mobilizers. The median number of previous attempts at stem cell collection was one and ranged between zero and four. Among a total of 69 failed stem cell collection regimens, the majority $(89.86 \%)$ involved chemotherapy plus G-CSF; G-CSF alone was used in four patients and $\mathrm{BM}$ aspiration in three patients $(5.79 \%$ and $4.35 \%$, respectively) (Table 2). Among the patients treated with plerixafor and G-CSF without chemotherapy, G-CSF $(10 \mu \mathrm{g} / \mathrm{kg})$ was administered as a single daily dose to 32 patients, whereas in 19 patients the dose was split into two daily injections $(2 \times 5 \mu \mathrm{g} / \mathrm{kg})$. Twenty-three patients (37.7\%) were in $\mathrm{CR}$ at the time of mobilization, 29 $(47.5 \%)$ in PR, six $(9.8 \%)$ had StD, and three $(4.9 \%)$ had PD. Among the patients with known data, 34 did not have

Table 2 Chemotherapy regimens used for failed stem cell mobilizations preceding mobilization with plerixafor and G-CSF

\begin{tabular}{lc}
\hline Chemotherapy regimen & Number of mobilization attempts \\
\hline HD-Cy & 25 \\
ICE & 7 \\
IVE & 7 \\
ESHAP & 4 \\
BEACOPP escalated & 3 \\
CED & 2 \\
Cy + etoposide & 3 \\
Dexa-BEAM & 2 \\
DHAP & 1 \\
R-ICE & 1 \\
HD-etoposide & 2 \\
BEACOPP & 1 \\
HyperCVAD & 1 \\
HAD-R & 1 \\
MA & 1
\end{tabular}

The abbreviations denote commonly used chemotherapy courses (look at http://chemoregimen.com/)
BM infiltration in the last trephine biopsy before mobilization, 11 had infiltration below 20\%, four between 20 and $49 \%$, and one above $50 \%$.

When analyzed in subgroups on the basis of their diagnosis (Table 1), the majority of patients with NHL and HL were male $(65 \%$ and $61 \%$, respectively), whereas the majority of patients with MM (56.5\%) were female. The median age of the patients with HL was the lowest, at 26 years, whereas the median age of patients with NHL and MM was 51 and 60 years, respectively. Almost $35 \%$ of the patients with MM had undergone autoSCT previously, in contrast to $5 \%$ of the patients with NHL and $11 \%$ of the patients with HL. The MM group was also characterized by the lowest proportion of patients in $\mathrm{CR}$ and without $\mathrm{BM}$ infiltration compared with the patients with NHL and HL (17.4\% vs. $45 \%$ vs. $55.6 \%$ and $30 \%$ vs. $86.7 \%$ vs. $100 \%$, respectively). The groups did not differ markedly with respect to median body weight, frequency of previous radiotherapy treatment, number of previous chemotherapy courses and regimens, or previous mobilization attempts.

The specific entry requirements of the CUP were waived for some patients with accompanying disorders who, in the opinion of the physician, would benefit from enrollment. Three patients (5.4\%) suffered from renal insufficiency as defined by each center; the overall median serum creatinine level was $0.8 \mathrm{mg} / \mathrm{dL}$ (range, 0.58-1.3). Three patients suffered from liver insufficiency. The median ALT level was $21 \mathrm{U} / \mathrm{L}$ (range, 3-126) and median total bilirubin was $0.52 \mathrm{mg} / \mathrm{dL}$ (range, 0.27-1.27). Another three patients suffered from heart failure, and the median ejection fraction was $65 \%$ (range, $40-76 \%$ ). In five out of 42 patients with known data $(11.9 \%$ ), the WBC count was $<2.5 \mathrm{G} / \mathrm{L}$, but the median PB WBC count in all patients was $4.4 \mathrm{G} / \mathrm{L}$ (range, 1.63-19.3). A Plt count below $85 \mathrm{G} / \mathrm{L}$ was observed in three patients ( $7.1 \%$ of patients with known data), and the overall median Plt count was 149 G/L (range, 61-442). The median $\mathrm{Hb}$ level was $11.8 \mathrm{mg} / \mathrm{dL}$ (range, 8.2-15.9).

In 10 patients, plerixafor was used in addition to a chemotherapy-based mobilization regimen. These patients were predicted to be poor mobilizers on the basis of low CD34+ cell numbers in the PB at optimal time points following chemotherapy plus G-CSF. In four patients, the chemotherapy regimen was ifosfamide, carboplatin, and etoposide (ICE); in two high-dose cyclophosphamide (HD-Cy); and single patients underwent mobilization after cyclophosphamide, etoposide, and dexamethasone (CED); bleomycin, etoposide, doxorubicin, cyclophosphamide, vincristine, procarbazine, and prednisone (BEACOPP); dose-escalated BEACOPP; and rituximab, methotrexate, cyclophosphamide, doxorubicin, vincristine, and prednisone (R-Mtx-MegaCHOP), respectively. The timing of the administration of plerixafor in this setting depended on individual decisions made by the investigators. 
PB CD34+ cells and apheresis yield

PB CD34+ cell counts after the first administration of plerixafor (before the first planned apheresis) were available for 52 patients. Data on the PB CD34+ cell count after the second and third injections of plerixafor were available for 32 and 14 patients, respectively (Fig. 1, Table 3). The median number of circulating CD34+ cells after the first administration of plerixafor was $22 / \mu \mathrm{L}$, ranging between 0 and $121 / \mu \mathrm{L}$. It exceeded the threshold number of 20 $\mathrm{CD} 34+$ cells $/ \mu \mathrm{L}$ in 31 patients $(58.5 \%)$. On days 2 and 3 , the median PB CD34+ count was 16 cells/ $\mu \mathrm{L}$ (range, 0.698 ) and 11 cells $/ \mu \mathrm{L}$ (range, 3-50), respectively. However, when analyzed in patients who had number of PB CD34+ cells assessed both on days 1 and $2(N=32)$, the median PB $\mathrm{CD} 34+$ cell counts on these days did not differ (median of $16 \mathrm{CD} 34+$ cells $/ \mu \mathrm{L}$ and range $0-121 \mathrm{CD} 34+$ cells $/ \mu \mathrm{L}$ on day 1 , and median of $16 \mathrm{CD} 34+$ cells $/ \mu \mathrm{L}$ and range of $0.6-$ $98 \mathrm{CD} 34+$ cells $/ \mu \mathrm{L}$ on day 2 ).

The mobilization regimen was associated with high leukocytosis on day 1 (median WBC $36.8 \mathrm{G} / \mathrm{L}$, range 1.1-92.1). Aphereses were performed in all but nine patients (i.e., in $85.2 \%$ ). The median number of days of apheresis was 2 days, and it ranged between 0 and 4 days. The median total number of CD34+ cells collected was $2.67 \times 10^{6} / \mathrm{kg}$ b.w., and ranged between 0 and $8.0 \times 10^{6} / \mathrm{kg} \mathrm{b}$. w. (Table 3). The procedure was associated with a high number of NCs in the stem cell product, and the median total count of NCs was $9.3 \times 10^{8} / \mathrm{kg}$ b.w. (range, $0-40.4$ ). The minimum target of $\geq 2.0 \times 10^{6} \mathrm{CD} 34+$ cells $/ \mathrm{kg}$ b.w. was collected in 40 patients $(65.6 \%)$. Among these patients, the median number of days of apheresis needed to exceed the level of $\geq 2.0 \times 10^{6} \mathrm{CD} 34+$ cells $/ \mathrm{kg}$ b.w. was 2 days and ranged between 1 and 3 days. During the first, second, and third days of apheresis, a median of $1.19,1.13$, and $0.8 \times$ $10^{6} \mathrm{CD} 34+$ cells $/ \mu \mathrm{L}$ was collected, respectively (Fig. 2). In those patients, in whom aphereses were performed both after first and second plerixafor administration $(N=41)$, the

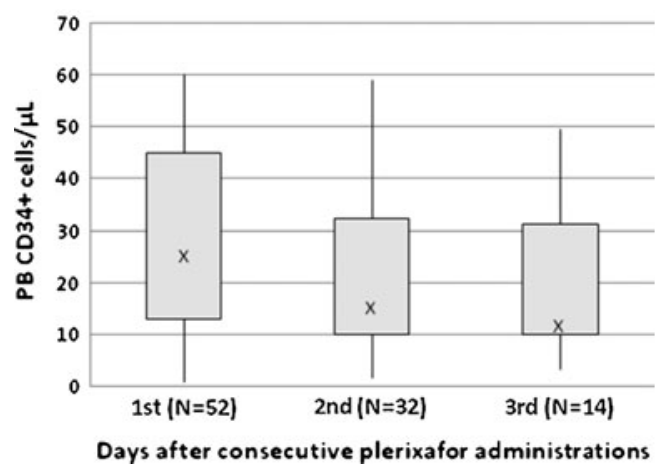

Fig. 1 Circulating peripheral blood CD34+ cells $/ \mu \mathrm{L}$ after each administration of plerixafor. Error bars represent the 10-90\% range, boxes represent the $25-75 \%$ range, $x$ represents the median yield of CD34+ cells did not differ between collections. In the first apheresis, the median of $1.14 \times 10^{6} \mathrm{CD} 34+$ cells $/ \mathrm{kg}$ b.w. (range, 0.01-2.7) was collected, while the median yield of second apheresis was $1.19 \times 10^{6} \mathrm{CD} 34+$ cells $/ \mathrm{kg}$ b.w. (range, 0.02-3.53).

When the patients were analyzed in subsets on the basis of their diagnosis, we observed the lowest WBC count after the first injection of plerixafor in patients with NHL (mean $28.2 \mathrm{G} / \mathrm{L}, p<0.05$ ), as well as the lowest PB CD34+ cell count (mean 19.8 CD34+ cells $/ \mu \mathrm{L}$ ) (Table 4). The PB $\mathrm{CD} 34+$ cell count exceeded 20 cells $/ \mu \mathrm{L}$ in only $36.8 \%$ of patients with NHL, compared with $84.2 \%$ of patients with MM and $53.3 \%$ of those with HL. Consequently, the lowest mean total $\mathrm{CD} 34+$ cell dose was collected from patients with NHL $\left(1.69 \times 10^{6} \mathrm{CD} 34+\right.$ cells $/ \mathrm{kg}$ b.w. $)$, compared with $2.99 \times 10^{6} \mathrm{CD} 34+$ cells $/ \mathrm{kg}$ b.w. from patients with $\mathrm{MM}$ and $2.98 \times 10^{6} \mathrm{CD} 34+$ cells $/ \mathrm{kg}$ b.w. from patients with HL $(p<0.05)$.

\section{Factors affecting the CD34+ cell yield}

Factors that could potentially influence the ability to collect at least $2.0 \times 10^{6} \mathrm{CD} 34+$ cells $/ \mathrm{kg}$ b.w. were assessed using univariate analysis (Table 5). The diagnosis of NHL was associated with the lowest proportion of patients who achieved the collection goal (40\%), as compared with patients with MM $(78.3 \%)$ or HL $(77.8 \%)(p<0.05)$. Similarly, $\geq 2.0 \times 10^{6} \mathrm{CD} 34+$ cells $/ \mathrm{kg}$ b.w were collected in only $40 \%$ of patients treated with radiotherapy, as compared with $73.9 \%$ of those who did not receive such treatment $(p<0.05)$. Importantly, mobilization was successful in all the patients who had been treated with plerixafor in firstline mobilizations, compared with successful mobilization in $58.8 \%$ of the remaining patients $(p<0.05)$. Mobilization also tended to be more successful in female as compared with male patients $(77.8 \%$ vs. $55.9 \%)$, in patients $\leq 40$ vs. $>40$ years of age $(80 \%$ vs. $58.5 \%)$, those treated with $\leq 12$ vs. $>12$ courses of chemotherapy $(73.5 \%$ vs. $55.6 \%)$, and those who received $\leq 3$ vs. $>3$ chemotherapy regimens ( $74.4 \%$ vs. $50 \%$ ); however, these differences were not significant. Importantly, mobilization was successful in only one out of seven patients $(14.3 \%)$ who were treated with purine analogs, as compared with $72.2 \%$ of patients who did not receive these drugs $(p<0.01)$. Similarly, the required number of $\mathrm{CD} 34+$ cells was collected in only $31.3 \%$ of patients treated with rituximab (anti-CD20), in contrast to $77.3 \%$ of the remaining patients $(p=0.001)$. Given that the characteristics of the patients and previous therapies differed considerably between cases of MM, NHL, and HL, a similar analysis was performed in the subsets of patients based on the diagnosis (Table 5). This analysis confirmed the above trends; however, the low number of patients in each subset contributed to the low 
Table 3 Outcomes of stem cell mobilization, collection, and transplantation

\begin{tabular}{|c|c|c|}
\hline Outcome & $N$ (number of participants) & Median (range) \\
\hline $\mathrm{CD} 34+$ cells $/ \mu \mathrm{L}$ after $1 \mathrm{st}$ dose of plerixafor & 52 & $22(0-121)$ \\
\hline CD34+ cells $/ \mu \mathrm{L}$ after 2 nd dose of plerixafor & 32 & $16(0.6-98)$ \\
\hline CD34+ cells $/ \mu \mathrm{L}$ after 3 rd dose of plerixafor & 14 & $11(3-50)$ \\
\hline WBC $(\mathrm{G} / \mathrm{L})$ after 1st application of plerixafor & 54 & $36.8(1.1-92.1)$ \\
\hline Number of days of apheresis & 61 & $2(0-4)$ \\
\hline Day of apheresis when $\geq 2.0 \times 10^{6} / \mathrm{CD} 34+$ cells $/ \mathrm{kg}$ was reached & 37 & $2(1-3)$ \\
\hline Total No. of CD34+ cells collected $\left(\times 10^{6} / \mathrm{kg}\right.$ b.w. $)$ & 61 & $2.67(0-8.0)$ \\
\hline Total No. of NCs collected $\left(\times 10^{8} / \mathrm{kg}\right.$ b.w. $)$ & 57 & $9.3(0-40.4)$ \\
\hline Volume $(\mathrm{mL})$ of frozen stem cell product & 46 & $652(169-2,300)$ \\
\hline No. of plerixafor injections & 55 & $2(1-4)$ \\
\hline Plerixafor single dose $(\mathrm{mg})$ per patient & 58 & $18.2(11.7-28.8)$ \\
\hline Plerixafor total dose $(\mathrm{mg})$ per patient & 55 & $42.5(12.7-102.7)$ \\
\hline Plerixafor ampoules per patient & 52 & $1.8(0.5-4.3)$ \\
\hline Days to neutrophil engraftment & 33 & $12(8-20)$ \\
\hline \multirow[t]{2}{*}{ Days to platelet engraftment } & 33 & $14(7-30)$ \\
\hline & $N$ (number of participants) & Proportion $(\%)$ \\
\hline Patients with $\geq 20 \mathrm{CD} 34+$ cells $/ \mu \mathrm{L}$ after 1 st dose of plerixafor & 31 & 58.5 \\
\hline Patients yielding $\geq 2.0 \times 10^{6} / \mathrm{CD} 34+$ cells $/ \mathrm{kg}$ b.w. & 40 & 65.6 \\
\hline Patients yielding $1.0-2.0 \times 10^{6} / \mathrm{CD} 34+$ cells $/ \mathrm{kg}$ b.w. & 3 & 4.9 \\
\hline Patients yielding $<1.0 \times 10^{6} / \mathrm{CD} 34+$ cells $/ \mathrm{kg}$ b.w. & 18 & 29.5 \\
\hline
\end{tabular}

power in the analysis. Multivariate analysis of the diagnosis and factors that were thought to be independent from diagnosis (gender, number of chemotherapy courses, and radiotherapy) confirmed the significance of the diagnosis of NHL $(p<0.05$; odds ratio, 6.73$)$ and previous radiotherapy $(p<0.05$; odds ratio, 5.49) as factors that contributed to an inferior outcome of stem cell collection (Table 6).

Assessment of the quantity of plerixafor used

A median of two injections of plerixafor (range, one to four) was administered in 55 evaluable patients (Table 3). On the basis of the patient's body weights, this translated

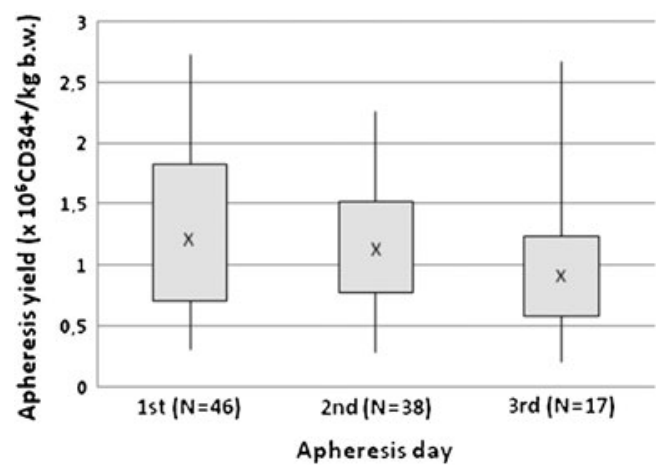

Fig. $2 \mathrm{CD} 34+$ cell yields by day of apheresis. Error bars represent the $10-90 \%$ range, boxes represent the $25-75 \%$ range, $x$ represents the median into a median of $42.5 \mathrm{mg}$ of drug used per patient (range, $12.7-102.7 \mathrm{mg}$ ), with a median single dose of $18.2 \mathrm{mg}$ (range, 11.7-28.8). Taking into account the fact that a single ampoule contains $24.0 \mathrm{mg}$ of the drug, the median number of ampoules used was 1.8 , ranging between 0.5 and 4.3 .

Transplantation and engraftment

Up to the last follow-up examination, 34/61 patients (55.7\%) who had participated in the CUP program had proceeded to autoSCT. Among the 40 patients from whom $\geq 2.0 \times 10^{6} \mathrm{CD} 34+$ cells $/ \mathrm{kg}$ b.w. were collected, $30 \mathrm{had}$ already undergone stem cell transplantation (SCT; 75.0\%), in contrast to the four of 21 patients $(19.0 \%)$ whose stem cell collection had failed. The conditioning regimens included carmustine, etoposide, cytarabine, and melphalan (BEAM) in 14 patients; melphalan $200 \mathrm{mg} / \mathrm{m}^{2}$ (MEL200) in 13 patients; melphalan $140 \mathrm{mg} / \mathrm{m}^{2}$ (MEL140) in two patients; and cyclophosphamide, etoposide, and carmustine (CBV), cyclophosphamide and total body irradiation (CyTBI), and BEAM plus dexamethasone (DexaBEAM) in one patient each. Among the 34 patients with known data, in 25 cases $(73.5 \%)$, the transplanted stem cell product consisted solely of cells mobilized after the plerixaforcontaining regimen. In nine patients $(26.5 \%)$, the transplanted stem cell product was composed of cells mobilized after the plerixafor-containing regimen mixed with cells 
Table 4 Major outcomes of stem cell mobilization and collection in patient subsets according to diagnosis

N.S. not significant

\begin{tabular}{|c|c|c|c|}
\hline Outcomes & Median (range) & Mean $( \pm \mathrm{SD})$ & $p$ \\
\hline \multicolumn{4}{|c|}{ WBC after 1st application of plerixafor (G/L) } \\
\hline $\operatorname{MM}(N=19)$ & $42(9.3-88.1)$ & $42.2( \pm 20.0)$ & \multirow[t]{3}{*}{$<0.05$} \\
\hline NHL $(N=18)$ & $22.3(1.1-72.5)$ & $28.2( \pm 19.9)$ & \\
\hline $\mathrm{HL}(N=17)$ & $38.8(14.1-92.1)$ & $44.0( \pm 21.2)$ & \\
\hline \multicolumn{4}{|c|}{$\mathrm{PB}$ CD34+ cells $/ \mu \mathrm{L}$ after 1 st dose of plerixafor } \\
\hline $\mathrm{MM}(N=19)$ & $30(11-74)$ & $33.7( \pm 17.2)$ & \multirow[t]{3}{*}{ N.S. } \\
\hline NHL $(N=19)$ & $13(0-65)$ & $19.8( \pm 22.4)$ & \\
\hline HL $(N=14)$ & $22(11-121)$ & $33.9( \pm 29.7)$ & \\
\hline \multicolumn{4}{|c|}{ Total No. of CD34+ cells collected $\left(\times 10^{6} / \mathrm{kg}\right.$ b.w. $)$} \\
\hline $\mathrm{MM}(N=23)$ & $2.8(0.6-5.5)$ & $2.99( \pm 1.5)$ & \multirow[t]{4}{*}{$<0.05$} \\
\hline NHL $(N=20)$ & $0.89(0-6.5)$ & $1.69( \pm 1.9)$ & \\
\hline \multirow[t]{2}{*}{$\operatorname{HL}(N=18)$} & $2.8(0-8.0)$ & $2.98( \pm 2.0)$ & \\
\hline & $N$ (number of participants) & Proportion $(\%)$ & \\
\hline \multicolumn{4}{|c|}{ Patients with $\geq 20 \mathrm{~PB}$ CD $34+$ cells $/ \mu \mathrm{L}$ after 1 st dose of plerixafor } \\
\hline $\mathrm{MM}(N=19)$ & 16 & 84.2 & \multirow[t]{3}{*}{$<0.01$} \\
\hline NHL $(N=19)$ & 7 & 36.8 & \\
\hline HL $(N=14)$ & 8 & 53.3 & \\
\hline \multicolumn{4}{|c|}{ Patients yielding $\geq 2.0 \times 10^{6} / \mathrm{CD} 34+$ cells $/ \mathrm{kg}$ b.w. } \\
\hline $\mathrm{MM}(N=23)$ & 18 & 78.3 & \multirow[t]{3}{*}{$<0.05$} \\
\hline NHL $(N=20)$ & 8 & 40.0 & \\
\hline HL $(N=18)$ & 14 & 77.8 & \\
\hline
\end{tabular}

obtained from previous or later mobilization procedures. The median dose of CD34+ cells transplanted was $2.8 \times$ $10^{6} / \mathrm{kg}$ b.w. and ranged between 0.94 and 5.4. In all patients, engraftment was achieved with a median time to neutrophil recovery $(>0.5 \mathrm{G} / \mathrm{L})$ of 12 days (range, 820 days) and a median time to platelet recovery $(>20 \mathrm{G} / \mathrm{L})$ of 14 days (range, 7-30 days) (Table 3). On the basis of the reports of 28 patients, no cases of late graft failure were observed within the period of the audit. The median period from autoSCT to the last report was 15.2 weeks and ranged between 0.3 and 51 weeks. In the group of 31 patients with known data, two patients $(6.45 \%)$ experienced continuous progression since autoSCT, and another three patients relapsed after 11,13 , and 18 weeks, respectively.

\section{Discussion}

Plerixafor (AMD3100, Mozobil) is a new drug in the field of HSC transplantation and is designed to be used in combination with G-CSF for stem cell mobilization in patients with myeloma or lymphoma. As shown recently in two multicenter randomized double-blind placebocontrolled studies, the effect of plerixafor and G-CSF is superior to that of G-CSF and placebo [10, 11]. Before the results of those studies were published, plerixafor had already been made available to American and European transplant centers free of charge within the manufacturer- funded CUP. This allowed physicians to use plerixafor in everyday clinical situations without the strict limitations of clinical trials. The first study conducted in the United States within the CUP revealed that the minimum requirement of $2.0 \times 10^{6} \mathrm{CD} 34+$ cells $/ \mathrm{kg}$ b.w. was collected from $66 \%$ of patients [14]. Since that time, a number of authors have reported an overall success rate of mobilization of $70-100 \%$ after the administration of plerixafor in combination with G-CSF [15-24]. However, the characteristics of the patients, local circumstances, and the number of doses of plerixafor available differed considerably between the studies and may have affected the outcome. Moreover, these studies involved small groups of patients, with a maximum number of 49 patients reported by Stiff et al. [17]. The uncertainty regarding how these results translate into clinical practice stimulated us to evaluate retrospectively the results of the CUP in Poland.

We managed to collect data regarding plerixafor-based stem cell mobilizations in 61 patients, which is the largest group following the report by Calandra et al. [14]. The primary goal of the study was to investigate the efficiency of plerixafor in stem cell mobilization, expressed as the number of circulating CD34+ cells and the total number of CD34+ cells collected during aphereses. In our group of patients, a median of 22 circulating CD34+ cells/ $\mu \mathrm{L}$ was observed after the first injection of plerixafor. Calandra et al.[14] did not report the relevant data for comparison, but in the study by Tricot et al. [15] the median PB CD34+ 


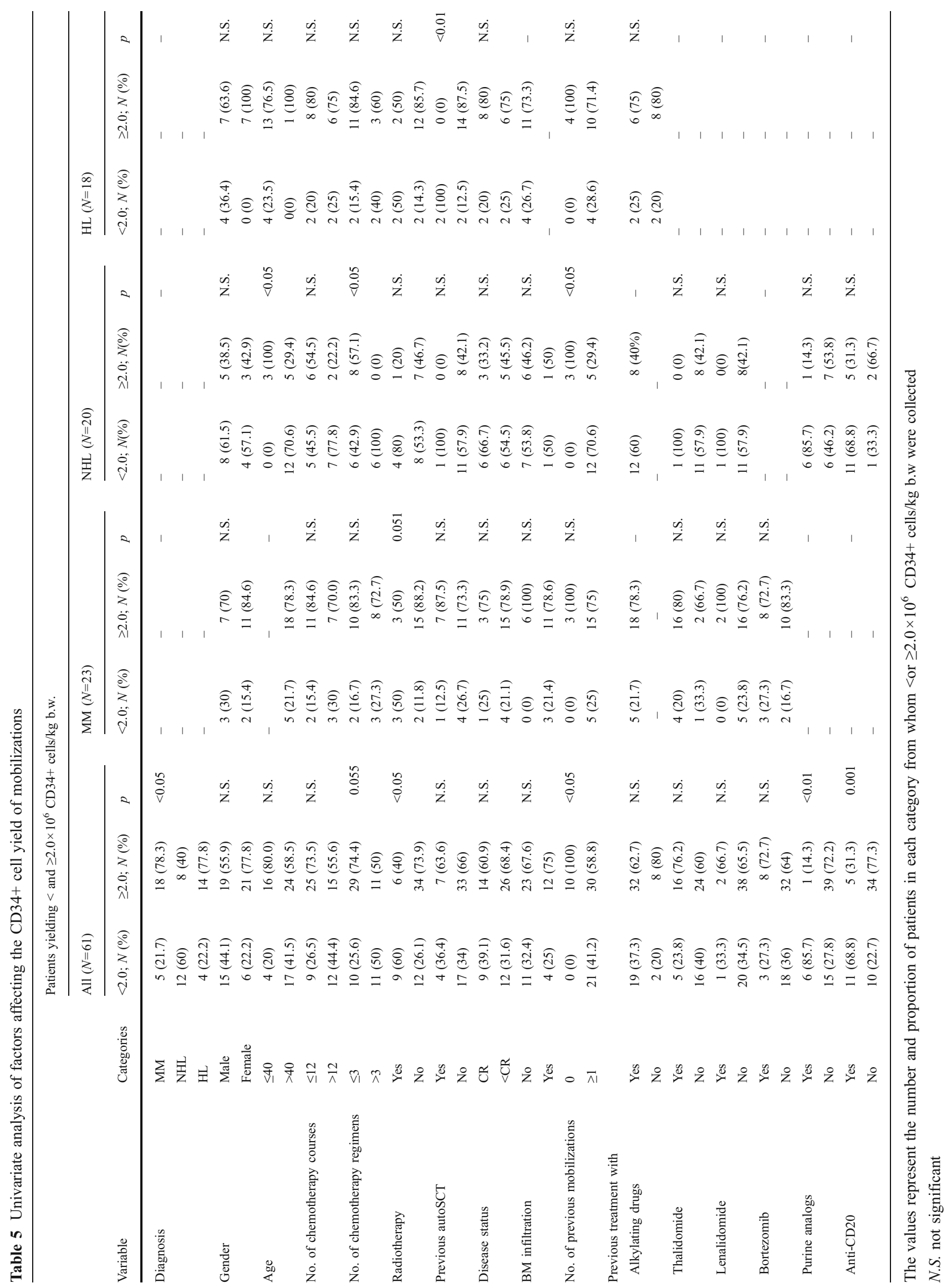


Table 6 Multivariate analysis of factors affecting the probability of collection of $<2.0 \times 10^{6} \mathrm{CD} 34+$ cells $/ \mathrm{kg}$ b.w.

\begin{tabular}{lll}
\hline Variable & $p$ & Odds ratio \\
\hline Diagnosis & & \\
MM & 0.017 & - \\
HL & 0.902 & 0.9 \\
NHL & 0.013 & 6.727 \\
Male gender & 0.484 & 1.636 \\
No. of chemotherapy courses $>12$ & 0.083 & 0.316 \\
Radiotherapy & 0.029 & 5.499 \\
\hline
\end{tabular}

cell count was only 6 cells $/ \mu \mathrm{L}$. In contrast, Stiff et al. and Fruehauf et al. reported a much higher median number of CD34+ cells: 56 cells $/ \mu \mathrm{L}$ and 69 cells $/ \mu \mathrm{L}$, respectively $[17,18]$. On the basis of the above-mentioned reports, it seems that this parameter depends largely on patient selection. The study of Tricot et al., which was similar to our study, investigated patients in whom previous mobilization attempts had failed. On the other hand, Stiff et al. and Fruehauf et al. presented data on patients in whom plerixafor was used as a first-line treatment. In the study of Fruehauf et al., a median of $22 \mathrm{CD} 34+$ cells $/ \mu \mathrm{L}$ was already observed after treatment with G-CSF alone, before the administration of plerixafor, and this value was identical to the median obtained in our study after injection of plerixafor [18]. Furthermore, we noted that the median number of PB CD34+ cells decreased after each administration of plerixafor, and a similar observation was made by Fowler et al. [16]. Similarly, the median CD34+ cell yield obtained in consecutive aphereses seemed to be decreasing. This phenomenon could indicate tachyphylaxis, i.e., a decrease in the response to plerixafor after repeated drug doses over a relatively short period of time. However, the results of these analyses seem to be biased by clinical practice of $\mathrm{CD} 34+$ cell enumeration and cell collection. Namely, in patients with satisfactory counts of circulating CD34+ cells after the first administration of plerixafor, apheresis was usually performed after the second and third injections of plerixafor without further assessment of CD34+ cells. Therefore, the median number of CD34+ cells $/ \mu \mathrm{L}$ after the second and third injections of plerixafor might reflect primarily the $\mathrm{PB} \mathrm{CD} 34+$ cell counts in patients who did not achieve satisfactory results on the first day, and therefore were lower. Similarly, in good mobilizers, who collected abundant number of CD34+ cells in the initial apheresis, the consecutive aphereses were not done, and thus these patients did not contribute to the analysis. The further results of our study seem to confirm these theses. Patients who had PB CD34+ cell measurements done both on days 1 and 2 mobilized similar number of CD34+ cells after first and second injection of plerixafor. Similarly, in those patients who underwent two aphereses, the CD34+ cell yield was similar in each of the collections. Based on above observations, the evidence for tachyphylaxis reaction in response to plerixafor could not be confirmed and needs to be further investigated in a larger cohort of patients.

In our study, $\geq 2.0 \times 10^{6} \mathrm{CD} 34+$ cells $/ \mathrm{kg}$ b.w., which is the minimum number required for SCT, were collected from $65.6 \%$ of patients. The success rate was similar to that reported by Calandra et al. [14] and lower than in the majority of the remaining reports. The median cell yield of $2.67 \times 10^{6} \mathrm{CD} 34+$ cells $/ \mathrm{kg}$ b.w. was lower than that in most studies. Differences in the procedures of cell collection could contribute to this finding. In our study, the median number of days of apheresis was 2 days, extending up to 4 days. In contrast, in the study by Calandra et al., the median number of days of apheresis was 3 days, ranging up to 7 days [14]. Tricot et al., who reported a very low median number of PB CD34+ cells, as discussed above, achieved a higher rate of success of collection (75\%) [15]. However, the majority of their patients underwent seven aphereses on consecutive days in order to achieve the goal of mobilization. Therefore, increasing the number of days of apheresis (and the number of injections of plerixafor) might increase both the total CD34+ cell yield and the success rate. Under normal clinical circumstances, the high cost of plerixafor and limited access to apheresis resources will certainly limit the number of days of apheresis to a minimum. Therefore, it is likely that our data give a better representation of the outcome of plerixafor-based mobilization than those obtained in other studies.

A diagnosis of NHL and previous radiation treatment were shown to be predictive factors for mobilization failure; they had been shown previously to have this effect in standard mobilizations [9, 25]. In addition, the observed trend towards inferior plerixafor-based mobilization in patients who had received multiple courses and regimens of chemotherapy and in patients treated with purine analogs has been documented previously in the context of standard approaches to mobilization [25, 26]. To our knowledge, we are the first to identify treatment with rituximab as a factor that affects stem cell mobilization adversely. This could be related to the role of B lymphocytes, which are the target of rituximab, in complement activation during stem cell mobilization [27]. Given that the heterogeneity of the patient group analyzed might affect the outcome of both univariate and multivariate analyses, we performed the analysis in subgroups that were separated on the basis of diagnosis. Unfortunately, sufficient data for statistical analysis could not be obtained from each of the diagnostic groups, owing to low patient numbers. Analysis of a larger cohort of patients is warranted. 
We have shown previously, on the basis of experience in a single center, that mobilization with plerixafor in combination with G-CSF is associated frequently with very high PB leukocytosis [24], and this was also confirmed in the current study. High leukocytosis has been shown previously to be related to an inferior outcome of stem cell collection [28]. This may potentially affect cell collections in European apheresis centers, which tend to use chemotherapy-based stem cell mobilization. In such cases, leukocytosis is usually much lower. High leukocytosis requires adaptation of the apheresis procedure to increase the separation of cell fractions, to maximize the use of CD34+ cells mobilized to the PB, and to avoid an abundance of NCs in the apheresis products. We have shown that the number of NCs in stem cell products is high, and in general, this increases the volume of frozen stem cell preparations.

Importantly, mobilization with plerixafor allowed progression to SCT in $55.7 \%$ of patients in whom previous mobilization attempts had failed. However, owing to the fact that the period from mobilization to the last follow-up was short, a number of patients from whom the required number of $\mathrm{CD} 34+$ cells had been collected had not received transplants at the time of the study. Moreover, some patients from whom fewer than $2.0 \times 10^{6} \mathrm{CD} 34+$ cells $/ \mathrm{kg}$ were collected after mobilization with plerixafor also benefited from the procedure. One of these patients has been transplanted successfully with $1.94 \times 10^{6} \mathrm{CD} 34+$ cells/ $\mathrm{kg}$ b.w, whereas several of them have received stem cell products pooled from several mobilizations, which were sufficient to provide the adequate number of CD34+ cells.

The potential risks of autoSCT after myeloablative conditioning are graft loss and delayed recovery of platelets and neutrophils. As shown in the current report, the cells mobilized with plerixafor engrafted in all cases, and a satisfactory time to platelet and neutrophil regeneration was observed, which was similar to or shorter than those reported by others [19-24]. However, one could argue that plerixafor mobilizes mostly the stem cell fractions that are responsible for short-term reconstitution of hematopoiesis, which could result in late graft failure. We did not observe such an event within the study period. There are several limitations of the study. The standard of care of the patients was not monitored, and the sites were not trained in the conduct of the CUP. In contrast to centers monitored by Calandra et al. [14], the clinicians had no prior experience with the drug and had to learn how to use it. However, paradoxically, these limitations might contribute to the value of the current study because it represents a real clinical situation, which is frequently far from that described in prospective clinical studies. The current report shows the benefit of stem cell mobilization with plerixafor in $65.6 \%$ of heavily pretreated patients who were poor or predicted to be poor mobilizers. Moreover, our data indicate a worse outcome of mobilization with plerixafor and G-CSF in patients suffering from NHL, as well as in patients who had been treated previously with radiotherapy, than in other groups.

Plerixafor was already approved in United States (2008) and in Europe (2009) for HSC mobilization in myeloma and lymphoma patients. Unfortunately, the cost of treatment with plerixafor is high, and despite the high efficiency of the drug, it is not reimbursed by health care providers in Poland and in most of European countries. Our report may help the physicians to optimize the use of plerixafor in patients with different pre-mobilization features.

Acknowledgements We would like to acknowledge sincerely all the physicians and laboratory staff taking part in the plerixafor CUP in Poland. We would also like to thank the drug manufacturer, Genzyme Corp., for providing plerixafor free of charge. We would also like to thank all the physicians and laboratory staff not mentioned as coauthors, who contributed to stem cell mobilization and to data collection.

Conflict of interest G.W.B. declares honoraria from Genzyme and reimbursements for participation in scientific conferences.

Open Access This article is distributed under the terms of the Creative Commons Attribution Noncommercial License which permits any noncommercial use, distribution, and reproduction in any medium, provided the original author(s) and source are credited.

\section{References}

1. Harousseau JL (2009) Hematopoietic stem cell transplantation in multiple myeloma. J Natl Compr Canc Netw 7(9):961-970

2. Moskowitz AJ, Moskowitz CH (2009) Controversies in the treatment of lymphoma with autologous transplantation. Oncologist 14(9):921-929. doi:10.1634/theoncologist.2009-0162

3. Gratwohl A, Baldomero H, Schmid O, Horisberger B, Bargetzi M, Urbano-Ispizua A (2005) Change in stem cell source for hematopoietic stem cell transplantation (hsct) in europe: a report of the ebmt activity survey 2003. Bone Marrow Transplant 36 (7):575-590. doi:10.1038/sj.bmt.1705104

4. Bender JG, To LB, Williams S, Schwartzberg LS (1992) Defining a therapeutic dose of peripheral blood stem cells. J Hematother 1 (4):329-341

5. Montgomery M, Cottler-Fox M (2007) Mobilization and collection of autologous hematopoietic progenitor/stem cells. Clin Adv Hematol Oncol 5(2):127-136

6. Bensinger W, DiPersio JF, McCarty JM (2009) Improving stem cell mobilization strategies: future directions. Bone Marrow Transplant 43(3):181-195. doi:10.1038/bmt.2008.410

7. Kucia M, Jankowski K, Reca R, Wysoczynski M, Bandura L, Allendorf DJ, Zhang J, Ratajczak J, Ratajczak MZ (2004) Cxcr4sdf-1 signalling, locomotion, chemotaxis and adhesion. $\mathrm{J}$ Mol Histol 35(3):233-245

8. Villalon L, Odriozola J, Larana JG, Zamora C, Perez de Oteyza J, Jodra MH, Lopez J, Herrera P, Roldan E, Ramos ML, Ramos P, Navarro JL (2000) Autologous peripheral blood progenitor cell 
transplantation with $<2 \times 10(6) \mathrm{cd} 34(+) / \mathrm{kg}$ : an analysis of variables concerning mobilisation and engraftment. Hematol J 1(6):374-381. doi:10.1038/sj/thj/6200057

9. Pusic I, Jiang SY, Landua S, Uy GL, Rettig MP, Cashen AF, Westervelt P, Vij R, Abboud CN, Stockerl-Goldstein KE, Sempek DS, Smith AL, DiPersio JF (2008) Impact of mobilization and remobilization strategies on achieving sufficient stem cell yields for autologous transplantation. Biol Blood Marrow Transplant 14 (9):1045-1056. doi:10.1016/j.bbmt.2008.07.004

10. DiPersio JF, Stadtmauer EA, Nademanee A, Micallef IN, Stiff PJ, Kaufman JL, Maziarz RT, Hosing C, Fruehauf S, Horwitz M, Cooper D, Bridger G, Calandra G (2009) Plerixafor and g-csf versus placebo and g-csf to mobilize hematopoietic stem cells for autologous stem cell transplantation in patients with multiple myeloma. Blood 113(23):5720-5726. doi:10.1182/blood-200808-174946

11. DiPersio JF, Micallef IN, Stiff PJ, Bolwell BJ, Maziarz RT, Jacobsen E, Nademanee A, McCarty J, Bridger G, Calandra G (2009) Phase iii prospective randomized double-blind placebocontrolled trial of plerixafor plus granulocyte colony-stimulating factor compared with placebo plus granulocyte colony-stimulating factor for autologous stem-cell mobilization and transplantation for patients with non-hodgkin's lymphoma. J Clin Oncol 27 (28):4767-4773. doi:10.1200/JCO.2008.20.7209

12. Cheson BD, Pfistner B, Juweid ME, Gascoyne RD, Specht L, Horning SJ, Coiffier B, Fisher RI, Hagenbeek A, Zucca E, Rosen ST, Stroobants S, Lister TA, Hoppe RT, Dreyling M, Tobinai K, Vose JM, Connors JM, Federico M, Diehl V (2007) Revised response criteria for malignant lymphoma. J Clin Oncol 25 (5):579-586. doi:10.1200/JCO.2006.09.2403

13. Durie BG, Harousseau JL, Miguel JS, Blade J, Barlogie B, Anderson K, Gertz M, Dimopoulos M, Westin J, Sonneveld P, Ludwig H, Gahrton G, Beksac M, Crowley J, Belch A, Boccadaro M, Cavo M, Turesson I, Joshua D, Vesole D, Kyle R, Alexanian R, Tricot G, Attal M, Merlini G, Powles R, Richardson P, Shimizu K, Tosi P, Morgan G, Rajkumar SV (2006) International uniform response criteria for multiple myeloma. Leukemia 20(9):14671473. doi:10.1038/sj.leu.2404284

14. Calandra G, McCarty J, McGuirk J, Tricot G, Crocker SA, Badel K, Grove B, Dye A, Bridger G (2008) Amd3100 plus g-csf can successfully mobilize cd34+ cells from non-hodgkin's lymphoma, hodgkin's disease and multiple myeloma patients previously failing mobilization with chemotherapy and/or cytokine treatment: compassionate use data. Bone Marrow Transplant 41(4):331-338. doi:10.1038/sj.bmt. 1705908

15. Tricot G, Cottler-Fox MH, Calandra G (2010) Safety and efficacy assessment of plerixafor in patients with multiple myeloma proven or predicted to be poor mobilizers, including assessment of tumor cell mobilization. Bone Marrow Transplant 45(1):63-68. doi:10.1038/bmt.2009.130

16. Fowler CJ, Dunn A, Hayes-Lattin B, Hansen K, Hansen L, Lanier K, Nelson V, Kovacsovics T, Leis J, Calandra G, Maziarz RT (2009) Rescue from failed growth factor and/or chemotherapy hsc mobilization with g-csf and plerixafor (amd3100): an institutional experience. Bone Marrow Transplant 43(12):909917. doi:10.1038/bmt.2008.409

17. Stiff P, Micallef I, McCarthy P, Magalhaes-Silverman M, Weisdorf D, Territo M, Badel K, Calandra G (2009) Treatment with plerixafor in non-hodgkin's lymphoma and multiple myeloma patients to increase the number of peripheral blood stem cells when given a mobilizing regimen of g-csf: implications for the heavily pretreated patient. Biol Blood Marrow Transplant 15 (2):249-256. doi:10.1016/j.bbmt.2008.11.028
18. Fruehauf S, Ehninger G, Hubel K, Topaly J, Goldschmidt H, Ho AD, Muller S, Moos M, Badel K, Calandra G (2010) Mobilization of peripheral blood stem cells for autologous transplant in nonhodgkin's lymphoma and multiple myeloma patients by plerixafor and g-csf and detection of tumor cell mobilization by pcr in multiple myeloma patients. Bone Marrow Transplant 45(2):269 275. doi:10.1038/bmt.2009.142

19. Hubel K, Fresen M, Lange F, Salwender H, Basara N, Bogner C, Galm O, Hartwig R, Dressler S, Ebinger M, Frickhofen N, Hertenstein B, Kiehl M, Liebler S, Von Lilienfeld-Toal M, Weidmann E, Weigelt C, Kroner N (2010) Plerixafor for stem cell mobilization in poor mobilizers: results from the german compassionate use programme. Bone Marrow Transplant 45 (Supplement 2):S316

20. Worel N, Rosskopf K, Nachbaur D, Kasparu H, Russ G, Namberger K, Leitner G, Kalhs P, Schogl E, Witt V, Greinix H, Keil F, Linkesch W (2010) Plerixafor plus g-csf can successfully mobilize cd34+ cells from patients who have previously failed chemotherapy and/or cytokine mobilization: the compassionate use experience in austria. Bone Marrow Transplant 45 (Supplement 2):S318

21. Mohty M, Lefrere F, Caillot D, Azar N, Miclea JM, Broussais F, Marolleau JP, Attal M, Milpied N, Gisselbracht C, Moreau P, Chabannon C (2010) Plerixafor plus g-csf can mobilize autologous haematopoietic stem cells from heavily pre-treated patients failing previous mobilization attempts: analysis of the french compassionate use programme. Bone Marrow Transplant 45 (Supplement 2):S319

22. Koristek Z, Folber F, Lysak D, Pohlreich D, Lanska M, Rusinakova Z, Papajik T, Kepak T, Novak J, Mayer J, Erba J (2010) The use of plerixafor in czech transplant centers. Bone Marrow Transplant 45(Supplement 2):S320

23. Jaksic O, Basic-Kinda S, Maricic I, Bojanic I, Nemet B, Pejsa V, Labar B (2010) Effective stem cell mobilization with plerixafor + g-csf followed by large-volume leukapheresis in poor mobilizers: the experience of the croatian cooperative group for hematologic diseases (krohem). Bone Marrow Transplant 45(Supplement 2):S321

24. Basak GW, Urbanowska E, Witkowska M, Zdunczyk D, Waszczuk-Gajda A, Skwierawska K, Drozd J, Skibinska M, Glazer M, Madry K, Halaburda K, Torosian T, Krol M, WiktorJedrzejczak W (2010) Stem cell mobilization with plerixafor in poorly mobilizing myeloma and lymphoma patients - a single centre experience and strategies. Bone Marrow Transplantation 45 (Supplement 2):S320

25. Bensinger W, Appelbaum F, Rowley S, Storb R, Sanders J, Lilleby K, Gooley T, Demirer T, Schiffman K, Weaver C et al (1995) Factors that influence collection and engraftment of autologous peripheral-blood stem cells. J Clin Oncol 13 (10):2547-2555

26. Ketterer N, Salles G, Moullet I, Dumontet C, ElJaafari-Corbin A, Tremisi P, Thieblemont C, Durand B, Neidhardt-Berard EM, Samaha H, Rigal D, Coiffier B (1998) Factors associated with successful mobilization of peripheral blood progenitor cells in 200 patients with lymphoid malignancies. Br J Haematol 103(1):235-242

27. Reca R, Cramer D, Yan J, Laughlin MJ, Janowska-Wieczorek A, Ratajczak J, Ratajczak MZ (2007) A novel role of complement in mobilization: immunodeficient mice are poor granulocyte-colony stimulating factor mobilizers because they lack complementactivating immunoglobulins. Stem Cells 25(12):3093-3100. doi:10.1634/stemcells.2007-0525

28. PA BEA, Winters JL (2003) Effects of high whole blood flow rates and high peripheral blood cell counts on cd34+ cell yield and cross-cellular contamination. Cytotherapy 5:446 